\title{
Assessing drivers of plantation forest productivity on eroded and non-eroded soils in hilly land, eastern North Island, New Zealand
}

\author{
Marie J Heaphy ${ }^{1 *}$, David J Lowe ${ }^{2}$, David J Palmer ${ }^{3}$, Haydon S Jones ${ }^{4}$, Gerty JHP Gielen ${ }^{1}$, Graeme R Oliver ${ }^{1}$
} and Stephen $\mathrm{H}$ Pearce ${ }^{1}$

\begin{abstract}
Background: The effect of soil erosion on New Zealand production forestry is not well known and there has been no research prior to our study into the relationship between soil nutrient status and planted forests growing in eroded soils in steeplands.

Methods: The impact of soil erosion by mass movement on forest productivity was investigated in a paired plot trial in a planted forest in a mainly hilly to steepland catchment (Pakuratahi) near Napier, eastern North Island, New Zealand. Tree growth and form were measured and soil properties analysed to compare productivity and productivity drivers in adjacent non-eroded and eroded plots.

Results: Regression analysis showed that the decreased soil total nitrogen, total carbon, total phosphorus, and soil organic matter content in eroded plots had a negative impact on tree volume, resulting in a $10 \%$ decrease in measured tree volume. Based on an assessment of log quality, trees in the eroded plots were forecast to produce $16 \%$ less volume from high-quality pruned logs (with associated reduction in revenue of around $\$ 4000$ per hectare), than trees in non-eroded plots. The total recoverable volume (TRV), estimated (for a 25-year rotation) from the measured Pinus radiata D. Don trees growing on the eroded sites, was valued at $\$ 68,500$, about $9 \%$ less than the estimated TRV from trees measured on non-eroded plots $(\$ 76,000)$. Tree form and mean tree height in eroded and non-eroded plots were not significantly different.

Conclusions: Soil erosion impacts production in planted forests. Afforestation of erodible land provides a valuable ecosystem service through land and soil stabilisation but this service is currently not reflected in the market prices for timber in New Zealand. Maintaining the productive capacity of erodible soils through practices such as fertilisation or continuous-cover forestry can add further costs to production forestry. To ensure that sustainable forest practices are carried out to protect the productivity of soils, financial incentives may be justified.
\end{abstract}

Keywords: Erosion; Planted forest; Hill country

\section{Background}

Erosion by mass movement is a common form of soil loss in steepland and hill country in New Zealand (Page et al. 1994). The east coast of the North Island is predominantly a mudstone/sandstone terrain capped in places with tephra deposits. This area became particularly susceptible to accelerated erosion following settlement by European farmers in the late $19^{\text {th }}$ Century when

\footnotetext{
* Correspondence: marie.heaphy@scionresearch.com

${ }^{1}$ Scion, Private Bag 3020, Rotorua, New Zealand

Full list of author information is available at the end of the article
}

much of the indigenous forest was removed and replaced with pasture. Subsequently, landsliding and other forms of soil erosion increased when subjected to intense rainfall events (Crozier 1986; Glade 1998; Page et al. 1994). Mass movement in the form of soil slips comprises shallow, rapid slides and flows involving soil and regolith (Lynn et al. 2009) leaving scars in source areas and debris tails (run-out deposits) in the landscape. The failure surface is typically planar and parallel to the ground surface and usually $<1 \mathrm{~m}$ deep (soil slips $>1 \mathrm{~m}$ deep are uncommon) (Lynn et al. 2009). Soil in the debris tail may be deposited 
within the same land unit or transported off-site downstream. The eroded scar surface is slow to re-vegetate (often $\geq 10$ years), and the rate of recovery is influenced by factors such as lithology, weathering rate (governing release of nutrients), fertility, water holding capacity, and climatic conditions (Blaschke et al. 2000).

The effect of soil erosion on New Zealand production forestry is not well known and there has been no research prior to this study into the relationship between decreased soil nutrients and planted forests growing in eroded soils. Research on pasture reduction following erosion, however, has been covered by a number of trials. In eroded Wairarapa hill country in the southern North Island of New Zealand, maximum production recovery occurred within 20 years but only to a level of $80 \%$ of the pre-eroded level (Rosser and Ross 2011; Lambert et al. 1984, 1993). Declines in productivity on hillslope pasture were measured at $2 \%$ per decade after forest removal (Trustrum et al. 1983). Research into the effects of erosion on productivity in the United States has mainly focused on temperate, arable croplands. Of the few national and international studies researching the effects of erosion on forest productivity, all found a decrease in tree volume. In the east coast of New Zealand, earlier research ${ }^{\mathrm{a}}$ examined the forest productivity of first-rotation Pinus radiata D. Don (radiata pine) in 20 paired plots on known eroded and adjacent control sites. A $10 \%$ reduction in mean tree diameter at breast height was found in the slip-eroded areas in addition to $26 \%$ less total stem volume per hectare and a lower yield of more valuable pruned logs. In the Queen Charlotte Islands of British Columbia, 49 landslides ranging in age from 1 to 155 years were surveyed and it was found that the trees on landslides averaging an age of 85 years produced around one half the wood volumes of normal second-growth stands of the same age (Smith et al. 1986). Landslides occurring in natural forests have been shown to have adverse effects on tree recovery, with reduced rates of biomass accumulation and a species composition different from that of the surrounding forest in Hawaii (Francescato et al. 2001) and in New Hampshire, USA (Restrepo et al. 2003).

The values of avoided erosion through afforestation and the other ecosystem services that forestry provides have been quantified (Barry et al. 2014) but these services are currently not reflected by market prices in New Zealand. Barry et al. (2014) concluded that where benefits to society outweigh costs to the forest owner, positive incentives should be legislated to promote afforestation of marginal land. In the current project, forest growth on erosion-prone soils was compared with tree growth in non-eroded soils in a plantation forest in mainly hilly land and steepland near Napier. The objectives were (1) to determine and compare soil nutrient status in eroded and non-eroded soils in a planted forest catchment (Pakuratahi) and to relate the findings to forest productivity, and (2) to estimate the decrease in timber values associated with the loss of soil by erosion in the Pakuratahi forest.

\section{Methods}

This research was carried out in a northern subcatchment of the Pakuratahi forest (Figure 1), which is managed by PanPac Forest Products Ltd. The Pakuratahi catchment is situated $21 \mathrm{~km}$ northwest of Napier, coastal Hawke's Bay, at latitude $39^{\circ} 20^{\prime} 57^{\prime \prime}$ and longitude $176^{\circ}$ 52' 30" (Figure 1).

The Hawke's Bay region experiences a variable climate with summer droughts and high intensity rainfall events (Thompson 1987). Mean annual rainfall ranges from $440 \mathrm{~mm}$ to $1300 \mathrm{~mm}$ with maximum daily rainfall ranging from $28 \mathrm{~mm}$ to $300 \mathrm{~mm}$ (NIWA 2010). Mean annual rainfall and temperature at Tangoio, $5 \mathrm{~km}$ north of the Pakuratahi catchment, are $1501 \mathrm{~mm}$ and $13.3^{\circ} \mathrm{C}$, respectively (Eyles and Fahey 2006). Pakuratahi catchment comprises 774 ha of mainly hilly land and steepland (more than $60 \%$ of the catchment contains slopes of $20^{\circ}$ or greater) with flat to moderately rounded hills or ridge tops, and narrow terraces in valley bottoms in the southern section of the catchment. Elevation ranges from $18 \mathrm{~m}$ to $355 \mathrm{~m}$ above sea level.

The main geological units underlying the Pakuratahi catchment are the Kaiwaka Formation, a Pleistocene sedimentary unit comprising calcareous sandstone, limestone, and conglomerate aged c. 1.7 million years and up to $100 \mathrm{~m}$ thick, and the underlying Petane Formation, an early Pleistocene succession of repetitive alternating sequences of limestone, sandstone, mudstone, and conglomerate dating back to c. 2.2 million years (Haywick et al. 1991; Lee et al. 2011). Tephra-derived soils, which mainly occur on the upper ridges and slopes, have developed in situ primarily in the Waimihia Tephra (deposited $3401 \pm 108$ calendar yr BP) and the Taupo Tephra (deposited $232 \pm 10$ AD) (Lowe et al. 2013) over sandstone of the Kaiwaka and Petane formations (Eyles and Fahey 2006). The main soil orders in the Pakuratahi catchment are Pallic Soils and Pumice Soils (New Zealand Soil Classification: Hewitt 2010). Recent Soils also occur in the south of the catchment around the Pakuratahi River (Newsome et al. 2008).

\section{Site selection}

Data from a digitised surface of erosion slips photographed after storm events between 1943 and 1994 (Fransen and Brownlie 1995) were used to select erosion scars for sampling. Erosion scars greater than 0.02 ha in area and covered by a 21-year-old first-rotation Pinus radiata plantation were selected and identified as suitable for field examination. Fifteen plots were established within the erosion scars and paired with 15 plots located on adjacent non-eroded (stable) land of similar aspect and slope (Figure 2). 


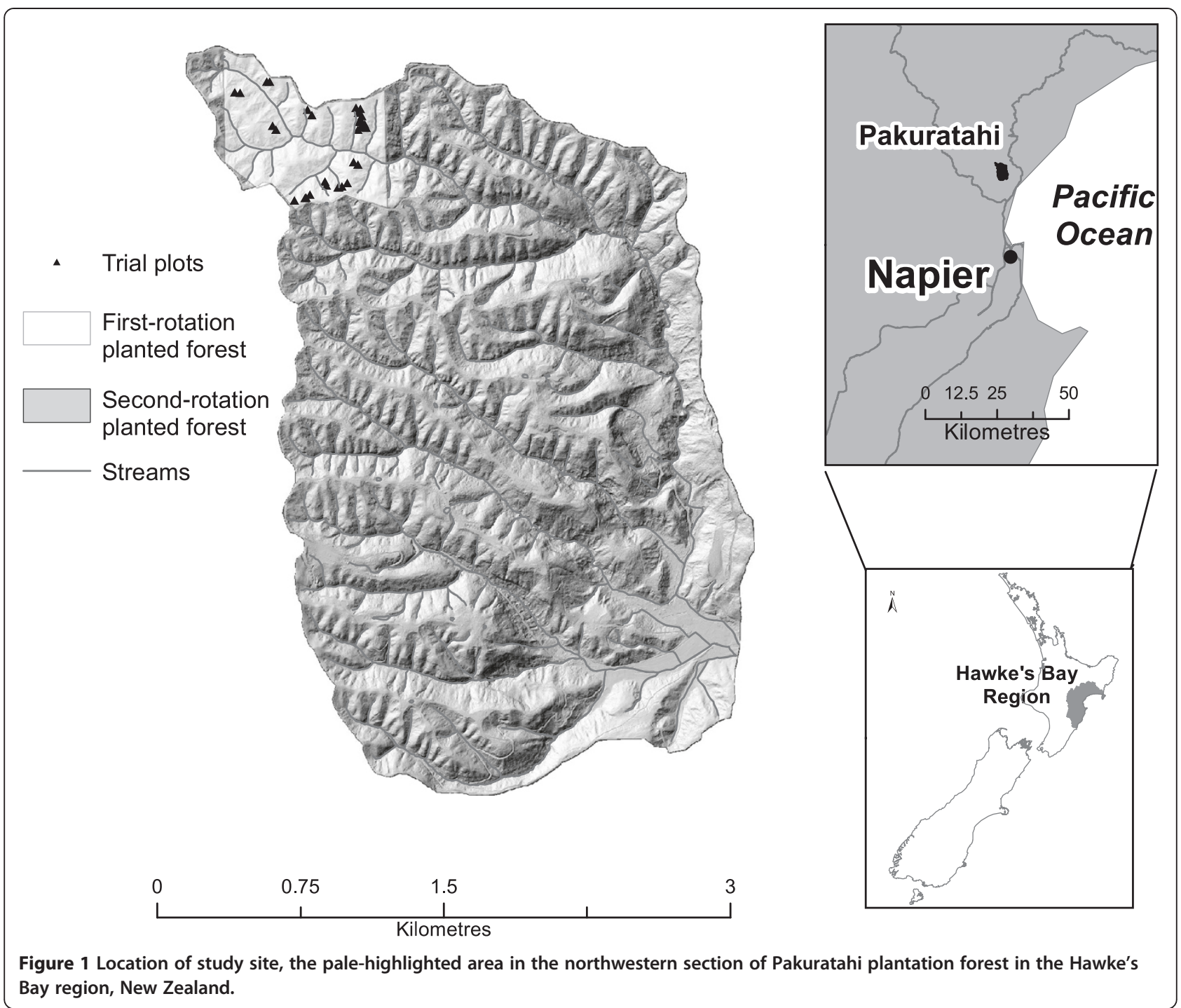

The number of trees available per plot ranged from 5 to 10 for the calculation of mean basal area with a total of 209 measured trees across the plots. Plot sizes ranged from 90 to $127 \mathrm{~m}^{2}$, slopes from 10 to $33^{\circ}$, and aspect from 2 to $358^{\circ}$. The plot locations were geo-referenced using a high-quality, global-navigation satellite system receiver (Trimble ProXRT). The raw data were differentially corrected using Trimble GPS Pathfinder Office Software (v5.3), a process which accesses the Land Information New Zealand (LINZ) network of base stations to improve survey-point accuracy.

\section{Field data collection}

Twenty soil samples per plot were collected for chemical analysis from 0 to $0.1 \mathrm{~m}$ depth using a small-diameter (23-mm) tube sampler. The samples were collected across each plot on a grid basis according to a stratified random pattern and were bulked for analysis on a per plot basis. Depth to impeding layer was assessed at each of the 20 sampling points using a $10-\mathrm{mm}$ diameter metal rod. Soil cores (0-0.1 m depth) for bulk density measurements were collected at three random locations throughout each slip using stainless steel rings of $98 \mathrm{~mm}$ internal diameter. Soil sampling was carried out to a depth of $10 \mathrm{~cm}$ to accommodate sampling in stony soils. Six observations per plot were made using a Dutch auger to determine the thickness (depth) of the A horizon. In each plot, trees were measured for diameter-atbreast height (DBH-measured at $1.4 \mathrm{~m}$ from the ground) and tree height. Individual tree form was recorded for tree growth and tree health. The presence of faults was summed per plot and a two-tailed $t$-test for the average of two means was performed to evaluate the difference. Tree-form characteristics were multi-leader (or malformed), forked or dead top, and leaning sweep and toppled but still alive (Ellis and Hayes 1997). 

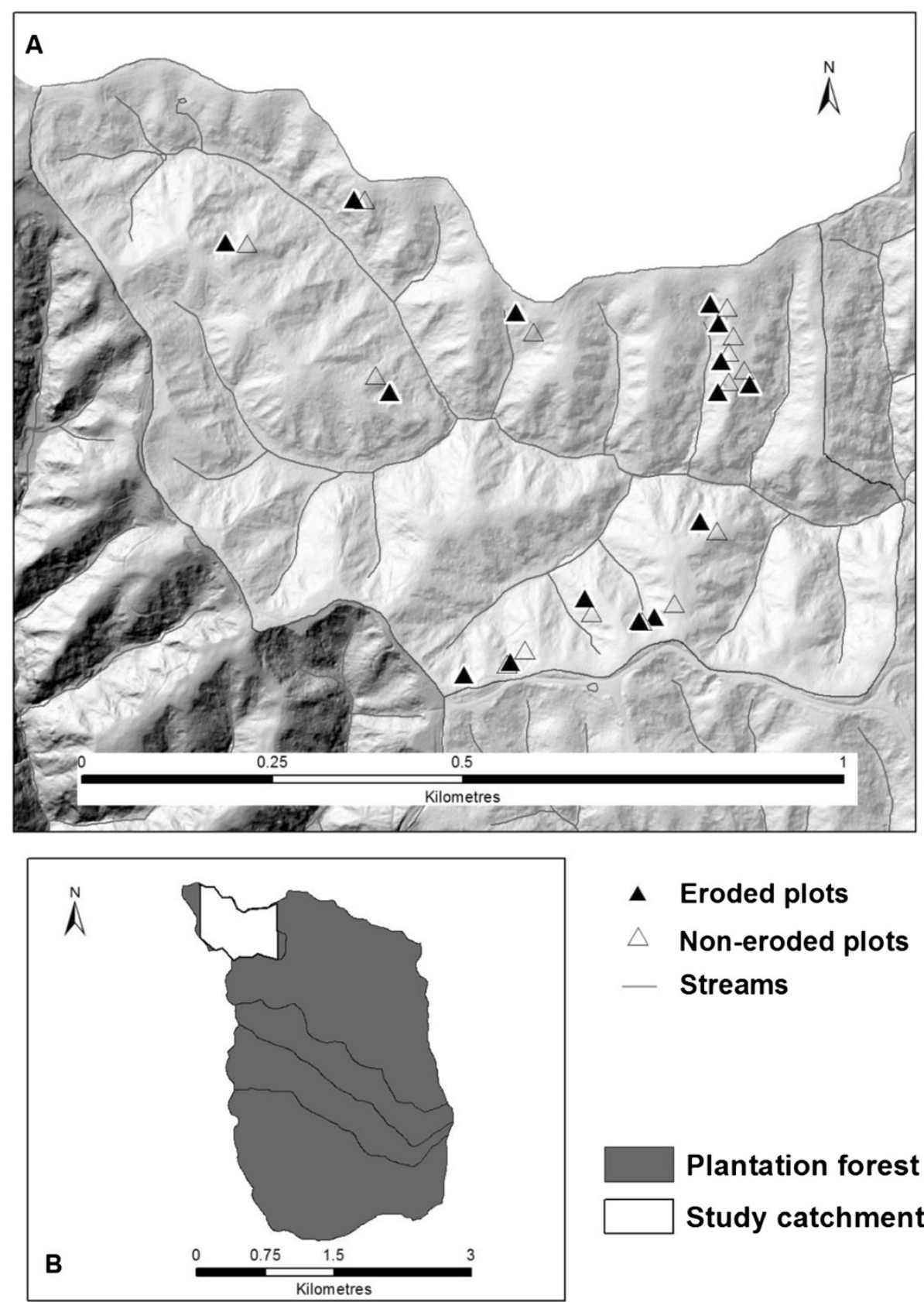

- Eroded plots

$\triangle$ Non-eroded plots

- Streams

\section{Plantation forest \\ Study catchment}

Figure 2 (A) Eroded and non-eroded paired plots for the study area, and (B) location within the Pakuratahi forest catchment (in white).

\section{Soil loss measurements}

The erosion scars used in this research were measured in the field. Only fourteen plot pairs were included in the final analysis because one erosion plot was washed out during an intense storm before the end of the trial. Depth and width measurements were taken at 5-m intervals along the length of each scar. Length measurements were adjusted for slope to determine the equivalent horizontal distance. Each scar was measured by suspending a stringline across the slip, first measuring the slip width and then its depth at the central position of the slip scar as set out in Page et al. (1999).

\section{Sample preparation and nutrient analysis}

Chemical analyses of soil samples taken from paired non-eroded control plots were used to estimate nutrient loss from each slip. The rationale for using soil results from control plots was to simulate the antecedent soil profile that had subsequently been lost through erosion. Soils were sampled to a depth of $0.1 \mathrm{~m}$ and results 
averaged across all plots. Soil samples for chemical analysis were air dried at $20^{\circ} \mathrm{C}$ and passed through a $2-\mathrm{mm}$ sieve (i.e. fine-earth fractions were analysed). Total carbon and total nitrogen were analysed by thermal combustion (Leco 2003). Total phosphorus was measured by flow injection analysis (FIA) colorimetry after sequential Kjeldahl digestion (Blakemore et al. 1987). Phosphorus availability was measured by FIA colorimetry after each of three sequential Bray-II extractions using 1:10 $\mathrm{NH}_{4} \mathrm{~F} / \mathrm{HCl}$ (Bray and Kurtz 1945; Skinner et al. 1991). Soil pH was determined using an electronic probe and a 1:2.5 soil-to-water ratio with distilled water $\left(1: 2.5 \mathrm{dH}_{2} \mathrm{O}\right)$. Soil organic matter content was measured by loss on ignition at $550^{\circ} \mathrm{C}$. Bulk density was determined from the oven-dry weight of bulked volumetric samples from each plot. Samples were air dried and sieved to $<2 \mathrm{~mm}$. The coarse $>2$ - $\mathrm{mm}$ material was discarded. The $<2-\mathrm{mm}$ fraction were oven dried at $105^{\circ} \mathrm{C}$ for 24 hours and then weighed again to determine oven-dry weight and fine fraction bulk density.

\section{Statistical analysis}

Paired $t$-tests for sample means were used to test for significant differences in soil properties, and tree height and volume, between the eroded and non-eroded sites. Relationships between measured soil properties and tree volumes were determined using the Microsoft 2010 regression analysis tool. A linear regression analysis was performed using the 'least squares' method to fit a line through the ratio of slip data over non-slip data.

\section{Prediction of growth: forecaster modelling}

Growth simulation software, Atlas Forecaster (West et al. 2012) was used to estimate the economic return from trees measured in this trial. The Forecaster software enables the modelling of potential revenue. Forest mensuration data consisting of tree height, DBH, and tree form, were converted into stem lists and imported into GeoMaster (forest activity planning and management software: Atlas 2012). PanPac Ltd provided additional silvicultural data including planting dates, stocking, pruning, and clearfell ages and the resulting analysis was based on a 22-year rotation (Table 1).

Table 1 Silvicultural regime for first-rotation planted forest

\begin{tabular}{lll}
\hline Date & Event & Stocking $\left(\right.$ stems ha ${ }^{-1}$ ) \\
\hline 1989 & Planting & 1200 \\
1994 & Pre-pruning & 1190 \\
1995 & Pre-pruning & 1190 \\
1997 & Pre-pruning & 1190 \\
1998 & Post waste thinning & 307 \\
2012 & Measurement & 307 \\
2014 & Pre clear fell & 298 \\
\hline
\end{tabular}

Additional information required for the model included accurate site locations and elevation, which were identified using a Trimble global positioning system (GPS). Data were captured using the New Zealand Transverse Mercator (NZTM) mapping projection defined in terms of the New Zealand Geodetic Datum 2000 co-ordinates system. The Atlas Forecaster model was used to investigate plantation forest data using standard Ministry of Agriculture and Forestry log grades for the cutting strategy and default function models specific to the site (MAF 2011a) (Table 2).

Log grades were established, determining log volume and value (MAF 2011a; 2011b) (Table 3) for pruned trees, structural timber, utility grade timber, and pulp.

\section{Results \\ Soil data}

The total surface area of both the 14 measured eroded plots and 14 non-eroded plots was 0.25 ha for each. Erosion scars ranged in size from 9 to $15 \mathrm{~m}$ in width, 12 to $24 \mathrm{~m}$ in length, and 0.5 to $2.3 \mathrm{~m}$ in depth. Based on estimated soil volume from the slip measurements and measured bulk density, a total of around 415 tonnes of soil was estimated to have been displaced from the 14 eroded sites. The average losses of nutrients are outlined in Table 4. Values of measured soil properties were significantly lower in eroded plots than non-eroded plots with the exception of bulk density and the mean thickness of the A horizon (Table 5).

Three sequential Bray-II extractions (Bray and Kurtz 1945; Skinner et al. 1991) were carried out to provide an indication of available $\mathrm{P}$ in soil solutions and also longterm P supply. Although the second and third extracts each contained lower amounts of P than the first extract, the amounts were still substantial. These results demonstrate the capacity the Pakuratahi soils have to supply P over a period of time in both eroded and non-eroded plots.

Table 2 Domestic log grades (MAF 2011a)

\begin{tabular}{lllll}
\hline Log grade & Log status & $\begin{array}{l}\text { Small end } \\
\text { diameter }(\mathbf{m m})\end{array}$ & $\begin{array}{l}\text { Maximum } \\
\text { knot }(\mathbf{m m})\end{array}$ & $\begin{array}{l}\text { Sweep } \\
\text { class }\end{array}$ \\
\hline P1 & Pruned & $400+$ & 0 & 1 \\
P2 & Pruned & $300-399$ & 0 & 1 \\
S1 & Unpruned & $400+$ & 60 & 1 \\
S2 & Unpruned & $300-399$ & 60 & 1 \\
S3 & Pruned or & $200-299$ & 60 & 1 \\
& unpruned & & & \\
L1 & Unpruned & $400+$ & 140 & 1 \\
L2 & Unpruned & $300-399$ & 140 & 1 \\
L3 & Unpruned & $200-299$ & 140 & 1 \\
Pulp & Unpruned & 100 & $\mathrm{n} / \mathrm{a}$ & 2 \\
\hline
\end{tabular}


Table 3 Log grades and prices measured in Japanese Agricultural Standard cubic metres, free on board (loaded onto a ship at export port) as at Dec 2012 (MAF 2011b)

\begin{tabular}{lll}
\hline Generic log type \& pricing point & $\begin{array}{l}\text { Dec-12 } \\
\text { quarter } \mathbf{( \$ )}\end{array}$ & $\begin{array}{l}\text { 12-quarter } \\
\text { average } \mathbf{( \$ ) ^ { \mathbf { a } }}\end{array}$ \\
\hline $\begin{array}{l}\text { EXPORT (NZ\$ per Japanese Agricultural } \\
\text { Standards } \mathrm{m}^{3} \text { free on board) }\end{array}$ & & \\
Pruned & $144-190$ & 168 \\
Unpruned A grade & $103-125$ & 126 \\
Unpruned K grade & $90-121$ & 116 \\
Pulp & $79-102$ & 109 \\
DOMESTIC (NZ\$ per tonne delivered at mill) & & \\
P1 & $122-149$ & 138 \\
P2 & $111-123$ & 118 \\
S1 & $95-104$ & 99 \\
S2 & $90-97$ & 95 \\
L1 and L2 & $77-96$ & 88 \\
S3 and L3 & $77-86$ & 81 \\
Pulp & $48-53$ & 51 \\
\hline
\end{tabular}

${ }^{a}$ Average log prices over preceding three years.

${ }^{b}$ Log prices can be quoted at a number of different pricing points, such as "cost insurance freight" (or c.i.f., i.e., landed at an importing port), "free on board" (or f.o.b., i.e., loaded onto a ship at an export port), wharf gate, on truck, and at stump.

Source: http://www.mpi.govt.nz/news-resources/statistics-forecasting/forestry/ indicative-new-zealand-radiata-pine-log-prices.aspx

\section{Tree growth and form}

Because of the small plot size (constrained by erosion scar size), average tree size within the study plots was used as a measure of productivity. A significantly larger mean DBH $(p=0.001)$ of $9 \%$ and a volume of $14 \%(p=$ 0.01 ) were recorded in trees from non-eroded plots compared with these parameters for trees measured in eroded plots. A two tailed t-test showed no difference in tree height and form with less than $1 \%$ difference between paired plots (Table 6).

\section{Soil properties and tree volume}

Ratios of eroded plot data to non-eroded plot data were used for a linear regression analysis to determine relationships between tree volume and measured soil properties (Table 7). Individually, the soil properties that

Table 4 Soil and soil nutrient loss estimated for 14 erosion plots in Pakuratahi (95\% confidence interval in parentheses)

\begin{tabular}{lll}
\hline & $\begin{array}{l}\text { Average per plot } \\
(\mathbf{n}=\mathbf{1 4})(\mathbf{k g})\end{array}$ & $\begin{array}{l}\text { Range across } \\
\text { plots }(\mathbf{k g})\end{array}$ \\
\hline Soil & $296814( \pm 133265)$ & $62737-870050$ \\
Total carbon & $5864( \pm 2408)$ & $1064-13920$ \\
Total nitrogen & $438( \pm 183)$ & $68-1131$ \\
Total phosphorus & $63( \pm 26)$ & $10-157$ \\
\hline
\end{tabular}

Table $\mathbf{5}$ Mean soil properties across all plots using a paired sample two-tailed $t$-test

\begin{tabular}{|c|c|c|c|c|}
\hline & Non-eroded & Eroded & \% Difference & Probability $^{\mathrm{a}}$ \\
\hline Total carbon (\%) & 3.7 & 2.0 & 47 & $* * *$ \\
\hline Total nitrogen (\%) & 0.3 & 0.1 & 52 & $* * *$ \\
\hline C:N ratio & 12.9 & 14.0 & 8 & * \\
\hline $\begin{array}{l}\text { Total phosphorus } \\
\left(\mathrm{mg} \mathrm{kg}^{-1}\right)\end{array}$ & 371.0 & 215.0 & 43 & $* * *$ \\
\hline $\begin{array}{l}\text { Soil organic } \\
\text { matter (\%) }\end{array}$ & 8.9 & 5.7 & 36 & $* * *$ \\
\hline $\begin{array}{l}\text { Bray-\|l P } 1^{\text {st }} \\
\text { extraction }\left(\mathrm{mg} \mathrm{kg}^{-1}\right)\end{array}$ & 52.0 & 33.0 & 36 & * \\
\hline $\begin{array}{l}\text { Bray-II P } 2^{\text {nd }} \\
\text { extraction }\left(\mathrm{mg} \mathrm{kg}^{-1}\right)\end{array}$ & 27.0 & 16.0 & 41 & * \\
\hline $\begin{array}{l}\text { Bray-\|l P } 3^{\text {rd }} \\
\text { extraction }\left(\mathrm{mg} \mathrm{kg}^{-1}\right)\end{array}$ & 16.0 & 10.0 & 38 & $*$ \\
\hline Soil pH & 5.6 & 5.5 & 3 & $*$ \\
\hline Mean soil depth (m) & 0.4 & 0.3 & 16 & $*$ \\
\hline $\begin{array}{l}\text { Mean A horizon } \\
\text { thickness }(m)\end{array}$ & 0.2 & 0.2 & 12 & ns \\
\hline Bulk density $\left(\mathrm{g} \mathrm{m}^{-3}\right)$ & 1.1 & 1.0 & 5 & ns \\
\hline
\end{tabular}

Probability: ${ }^{* * *} p=0.001 ;{ }^{* *} p=0.01 ;{ }^{*} p=0.05 ;$ ns $=$ not significant.

were most strongly related to volume increment were total carbon, nitrogen and phosphorus, and soil organic matter. Multilinear regression of soil properties combined did not result in any significant relationships.

\section{Effect of erosion on recoverable volume and log value}

The economic returns from a planted forest can vary depending on the quality of logs harvested. The calculated total recoverable log volume was $10 \%$ lower in eroded plots than in non-eroded plots. Eroded plots yielded $16 \%$ less volume from high-quality pruned logs, which accounted for a reduction in revenue of around $\$ 4,000$ per hectare at eroded sites. However, eroded plots had higher volumes of lower grade sawlogs (S2, S3, and L3) than in non-eroded plots (Figure 3). A reduction in total recoverable revenue was estimated at $\$ 7,500$ per hectare on eroded sites. Total recoverable volume (TRV) estimated (for a 25-year rotation) for Pinus radiata growing on the eroded sites was valued at $\$ 68,494$, which is $9 \%$ lower than the estimated TRV from trees growing on non-eroded plots $(\$ 75,989)$ (Figure 4 ).

Table 6 Mean tree properties across all plots using a paired sample two-tailed $t$-test

\begin{tabular}{llll}
\hline Characteristic & Non-eroded & Eroded & Probability $^{\text {a }}$ \\
\hline $\mathrm{DBH}$ & $493 \mathrm{~mm}$ & $536 \mathrm{~mm}$ & $* * *$ \\
Height & $40 \mathrm{~m}$ & $36 \mathrm{~m}$ & $\mathrm{~ns}$ \\
Form & 1.1 & 1.0 & $\mathrm{~ns}$ \\
\hline
\end{tabular}

${ }^{\text {aProbability: }}{ }^{* * *} p=0.001 ; \mathrm{ns}=$ not significant. 
Table 7 Summary of linear regression analysis between the ratios of eroded to non-eroded soil properties and Pinus radiata tree volume

\begin{tabular}{llll}
\hline $\begin{array}{l}\text { Ratio of eroded to non-eroded } \\
\text { soil data }\end{array}$ & Slope & $\boldsymbol{p}$ value & Probability $^{\mathbf{a}}$ \\
\hline Total carbon & 0.2 & 0.0154 & $* *$ \\
Total nitrogen & 0.2 & 0.0136 & $* *$ \\
Soil organic matter & 0.2 & 0.0183 & $* *$ \\
Total phosphorus & 0.2 & 0.0324 & $*$ \\
Carbon to nitrogen ratio & -0.4 & 0.2512 & ns \\
Soil pH & -1.7 & 0.2122 & ns \\
Mean soil depth & -0.3 & 0.2113 & ns \\
Mean A horizon thickness & 0.1 & 0.1537 & ns \\
Bulk density & -0.1 & 0.8678 & ns \\
\hline
\end{tabular}

${ }^{\text {a Probability: }}{ }^{* *} p=0.01 ;{ }^{*} p=0.05 ;$ ns $=$ not significant.

\section{Discussion}

Nutrients required by growing trees are provided by the soil and are immobilised in tree tissues in the early stages of tree growth and development (Attiwill and Adams 1993). Trees become more dependent on nutrient cycling within the forest ecosystem when canopy closure is reached, receiving inputs from breakdown of forest litter and the atmosphere (Carnol and Bazgir 2013). Hence trees planted in eroded sites may be disadvantaged in the early stages of growth because of the absence of topsoil and forest litter. In the study, trees growing in eroded soils were found to be significantly smaller in volume compared with trees in non-eroded soils. These trees were a first-rotation crop, planted in scrubby pastureland and aged 21 years at the time they were measured.
Analysis of soils from the trial plots showed significantly fewer nutrients in eroded plots compared with noneroded plots. In addition, regression analysis indicated a significant correlation between reduced amounts of $\mathrm{C}, \mathrm{N}$, $\mathrm{P}$, and soil organic matter in eroded plots, and smaller tree volume. Although no one variable stands out as the main contributor to a lesser tree volume, each deficiency appears to have made an impact. The relationship between tree volume and $\mathrm{P}$ was not as strong as the relationships between tree volume and $\mathrm{C}, \mathrm{N}$, and organic matter.

Measured soil carbon has been found to decrease following afforestation of grasslands with $P$. radiata (Parfitt and Ross 2011) but increases over time as pine litter accumulates, resulting in a higher soil total $\mathrm{C}$ content (Davis and Condron 2002; Paul et al. 2002; Laganière et al. 2010). An increase in soil nutrients over time due to litter accumulation is quite likely to occur at Pakuratahi, but it is not certain how much of an impact litter has had on eroded sites because the ages of the erosion scars are difficult to determine. At the same time, inadequate levels of inorganic nutrients such as nitrogen and phosphorus in soils of existing erosion scars will have had an effect on tree growth and therefore on the rate and amount of organic matter accumulation.

Phosphorus deficiency is a common limiting factor in plantation forestry even though $P$. radiata has the advantage over some other plant species of being able to access soil organic $\mathrm{P}$ because of an association between radiata pine roots and ectomycorrhizal fungi (Davis and Lang 1991; Davis et al. 1996). In the current study, soil total P levels were found to be significantly lower in

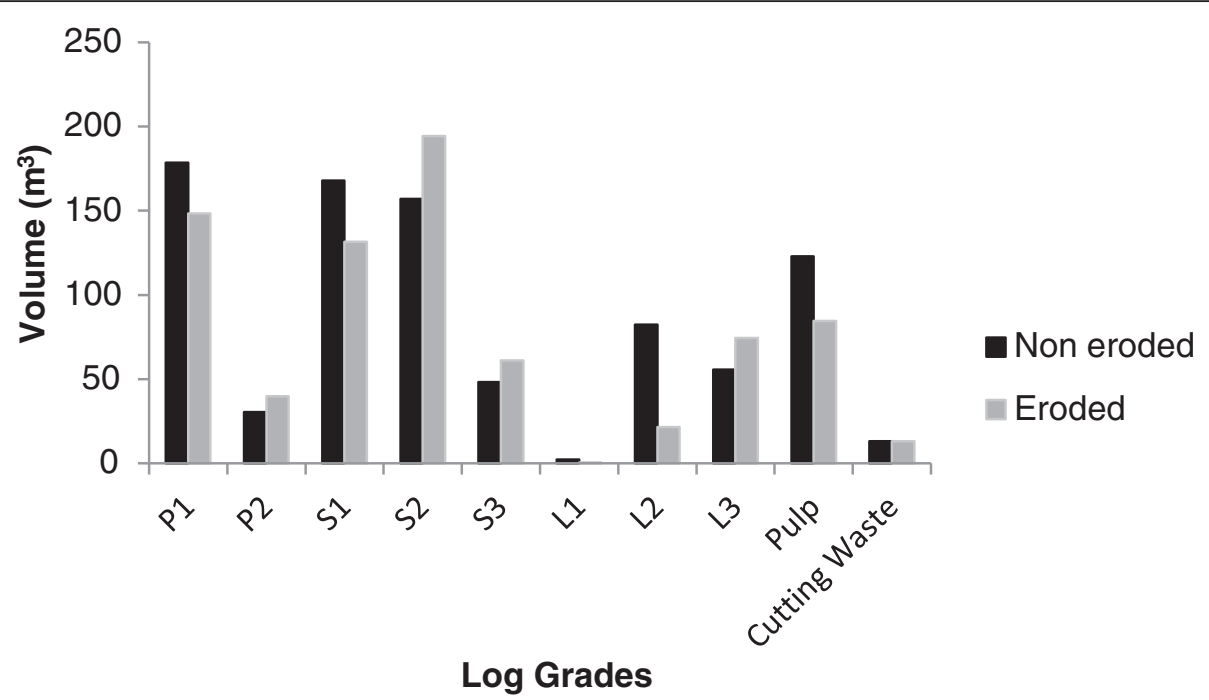

Figure 3 Total log volumes for log grades at eroded and non-eroded plots estimated for a 25 -year-old $P$. radiata rotation. Pruned sawlogs (P): appearance-grade timber; small-branch sawlogs (S): structural timber; large-branch sawlogs (L): industrial-appearance timber; residual logs: pulp and panel products (Pine Manufacturers 2013). 


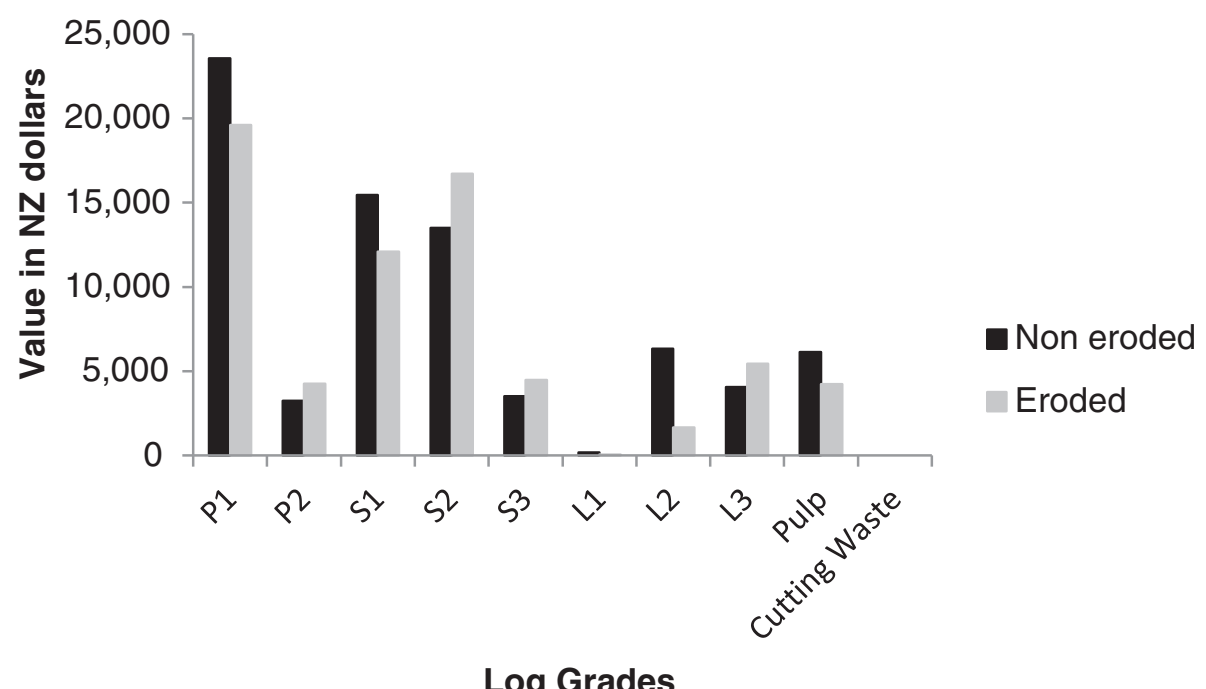

Figure 4 Log values for log grades in eroded and non-eroded plots. $P=$ pruned trees: high-quality straight logs; $S=$ unpruned (structural timber); $L=$ unpruned (utility timber); pulp for paper; cutting waste which is left onsite.

eroded plots compared with levels in non-eroded plots. In addition, the concentrations of $\mathrm{P}$ in sequential Bray-II $\mathrm{P}$ extractions of soil from eroded plots were below the $12 \mathrm{mg} \mathrm{kg}^{-1}$ level recommended for seedling establishment (Ballard 1970). This result suggests that P concentrations in eroded plots were possibly limiting growth of $P$. radiata in the long term. This view is supported by the values of the initial Bray-II extractions of eroded soils which were nearly half the values of soils in noneroded plots, thereby suggesting that the difference in $\mathrm{P}$ supply is associated with the difference in tree volume.

The positive relationship between nitrogen and tree volume agrees with the results from previous studies that examined tree volume response to nitrogenous fertilisers. An increase in volume increment of around $8 \mathrm{~m}^{3} \mathrm{ha}^{-1} \mathrm{yr}^{-1}$ following nitrogen application was found in research carried out on New Zealand soils from the central North Island in planted $P$. radiata stands (Mead and Gadgil 1978). Responses to $\mathrm{N}$ and $\mathrm{P}$ fertilisers on less fertile soils in Nelson were up to $17 \mathrm{~m}^{3} \mathrm{ha}^{-1} \mathrm{yr}^{-1}$ (Mead \& Gadgil 1978). In South Australia, near Mt Gambier, nitrogen fertiliser applications resulted in increased basal area increment after two years when applied prior to thinning (Carlyle 1995).

The 10\% decrease in total net volume forecast for trees in eroded plots compared to that for trees in noneroded plots is comparable to earlier research ${ }^{\mathrm{b}}$ carried out in Pakuratahi. Forest productivity was examined in a first-rotation $P$. radiata plantation at 20 paired plots on known eroded and adjacent control (non-eroded) land under an earlier first-rotation regime of planted forest in the Pakuratahi catchment. Their study found a $26 \%$ decrease in stem volume, with a lower yield of more valuable pruned logs. In British Columbia, Canada, logs from non-eroded land produced three times the volume of wood compared with volumes of logs removed from areas eroded by landslides aged 30 to 59 years (Smith et al. 1986). Logs from eroded sites where tree age averaged 85 years were around one half the volume of normal second-growth stands of the same age.

At Pakuratahi, the forecasted revenue was $\$ 7,500$ per hectare less for total recoverable volume (TRV) and $\$ 4,000$ less per hectare for high-quality pruned logs from eroded plots. A reduction of revenue of this size may not be sufficient to warrant active management changes such as fertilisation of eroded land. However, the Pakuratahi planted forest is considered to be a highproduction forest with a 300 index $^{\mathrm{b}}$ rating ranging from 30 to 40 (Palmer et al. 2010). The east coast climate is highly variable with summer droughts and high intensity rainstorms from northern tropical cyclones and cold southerlies from Antarctica (Salinger and Mullan 1999). Hill-country forest land is vulnerable to intense rainstorms, particularly post-harvest when the soils are exposed. Site-specific management studies and economic analysis could determine whether fertilisation will provide an economic advantage in improving long-term productivity.

Following extreme weather events, such as Cyclone Bola (1988), there has been a move toward the afforestation of potentially unstable land with permanent and production forests, particularly in the worst-hit regions such as the east coast of the North Island. Government incentives supporting afforestation in New Zealand tend 
to focus on mitigating the effects of greenhouse gases such as carbon. However, the results presented here have shown that there is a cost to the land owner/manager for growing trees on formerly eroded land because of resultant smaller log volumes. The economic value of erosion prevention as a result of production forestry is not currently recognised in the returns from forest products in New Zealand. Nevertheless, the annual cost of erosion to New Zealand has been estimated to be around $\$ 200$ million (Dymond et al. 2012).

A framework to capture the natural capital and ecosystem services provided by forestry in New Zealand would help to identify key ecosystem services that are not currently recognised economically, such as planting of $P$. radiata for erosion control (Jones et al. 2008). A recent framework developed for dairy farm soils identified a greater value from regulating than provisioning types of ecosystem services (Dominati et al. 2011). In forestry only the provisioning services of log production are valued. Regulating services such as slope stability and erosion control (Phillips et al. 1989) provision of habitat (Pawson et al. 2008; Bremer and Farley 2010) flood control (Serengil et al. 2011) and the filtering of contaminants and nutrients near waterways (Dymond et al. 2010) are yet to be incorporated into the benefits economically recognised in production forestry. If these services attracted financial benefits, land managers might be encouraged to explore alternative management methods to promote sustainable forestry and long-term site productivity.

\section{Conclusions}

Mass movement erosion in the Pakuratahi planted forest has resulted in a series of slips with associated erosion scars throughout the hilly and steepland catchment. Significantly lower levels of soil nutrients were detected in eroded soils than in non-eroded soils. This resulted in $47 \%$ less total carbon, $52 \%$ less total nitrogen, $43 \%$ less total phosphorus, and $36 \%$ less soil organic matter in the eroded topsoils compared with the non-eroded soils. These decreased levels of soil nutrients and soil organic matter significantly impacted on trees in eroded plots, resulting in a $10 \%$ decrease in volume compared with that of trees in non-eroded plots. The forecast value of these smaller logs means that trees grown in eroded sites are estimated to return a total recoverable volume of $\$ 7,500$ per hectare less than that of trees growing in non-eroded sites. The loss in revenue is borne by the land or forest owner but could be offset if the ecosystem service of avoided erosion were recognised financially. If the costs and mitigation of the erosion-related loss in productivity prove to be too much for future forestry operations in hill country, government financial incentives may be warranted as a viable economic option to sustain the regulating services provided by forestry.

\section{Endnotes}

${ }^{a}$ Dean, M, \& Heron, C. (1998). The effect of historical soil erosion on tree quality and volume: Report No. 58, Forest and Farm Plantation Management Cooperative. Unpublished.

${ }^{\mathrm{b}}$ The 300 Index defines the stem volume mean annual increment (MAI) at age 30 years for a reference regime of 300 stems ha $^{-1}$ (Kimberley et al. 2005).

\section{Competing interests}

The authors declare that they have no competing interests.

\section{Authors' contributions}

DJL contributed to trial design, supervised thesis underpinning project, co-wrote paper. DP contributed to research conceptual design, supervised thesis underpinning project, co-wrote paper. HJ Assisted with project development, supervised thesis underpinning project, co-wrote paper. GG assisted with data analyses and interpretation, supervised thesis underpinning project, co-wrote paper. GO assisted with trial design, plot establishment, slip descriptive measurements, reviewed paper and assisted with rewrite in response to refereeing comments. SP assisted with trial design, plot establishment, technical field data collection and sample preparation for analysis. All authors read and approved the final manuscript.

\section{Acknowledgements}

This research was supported by the New Zealand Ministry for Science and Innovation through the Future Forest Research Programme "Protecting and Enhancing the Environment through Forestry" (Contract C04X0806). We acknowledge the assistance provided by PanPac Forests Ltd, and particularly Brett Gilmore and Brian Garnett who provided access to the forest and logistical support. We also thank Scion colleagues for invaluable support: Loretta Garret, Jason Bennett, Mark Kimberley, Peter Beets, Rod Brownlie, Duncan Harrison, Ruth Falshaw, Veritec Laboratory, and the Scion Knowledge Centre. Peter Clinton and Ruth Falshaw furnished valuable editorial comments. Additional assistance was provided by former University of Waikato technician Craig Hosking, and Kyle Bland of GNS Science, Wellington.

\section{Author details}

${ }^{1}$ Scion, Private Bag 3020, Rotorua, New Zealand. ${ }^{2}$ School of Science, University of Waikato, Private Bag 3105, Hamilton 3240, New Zealand. ${ }^{3}$ Landcare Research, Private Bag 3127, Hamilton 3240, New Zealand. ${ }^{4}$ Waikato Regional Council, Private Bag 3038, Hamilton 3240, New Zealand.

Received: 14 April 2014 Accepted: 23 September 2014

Published online: 22 October 2014

\section{References}

Atlas. (2012). Geomaster: Forest activity planning and management. http:// atlastech.integral.co.nz/products/geomaster-range/.

Attiwill, PM, \& Adams, MA. (1993). Nutrient cycling in forests. New Phytologist, 124(4), 561-582.

Ballard, R. (1970). The phosphate status of the soils of Riverhead Forest in relation to growth of radiata pine. New Zealand Journal of Forestry, 15(1), 88-99.

Barry, LE, Yao, R, Harrison, DR, Paragahawewa, U, \& Pannell, DJ. (2014). Enhancing ecosystem services through afforestation: How policy can help. Land Use Policy, 39, 135-145.

Blakemore, LC, Searle, PL, \& Daly, BK. (1987). Methods for chemical analysis of soils. New Zealand Soil Bureau Scientific, Report 80. Wellington: New Zealand Soil Bureau.

Blaschke, PM, Trustrum, NA, \& Hicks, DL. (2000). Impacts of mass movement erosion on land productivity: A review. Progress in Physical Geography, 24(1), 21-52

Bray, RH, \& Kurtz, LT. (1945). Determination of total, organic and available forms of phosphorus in soils. Soil Science, 59, 39-45.

Bremer, LL, \& Farley, KA. (2010). Does plantation forestry restore biodiversity or create green deserts? A synthesis of the effects of land-use transitions on plant species richness. Biodiversity and Conservation, 19(14), 3893-3915. 
Carlyle, JC. (1995). Nutrient management in a Pinus radiata plantation after thinning: the effect of nitrogen fertilizer on soil nitrogen fluxes and tree growth. Canadian Journal of Forest Research, 25(10), 1673-1683.

Carnol, M, \& Bazgir, M. (2013). Nutrient return to the forest floor through litter and throughfall under 7 forest species after conversion from Norway spruce. Forest Ecology and Management, 309, 66-75.

Crozier, MJ. (1986). Landslides: causes, consequences and environment. New Hampshire, USA: Croom Helm.

Davis, MR, \& Condron, LM. (2002). Impact of afforestation on soil carbon in. New Zealand: A review of paired site studies Australian Journal of Soil Research, 40(4), 675-690

Davis, MR, \& Lang, MH. (1991). Increased nutrient availability in topsoils under conifers in the South Island high country. New Zealand Journal of Forestry Science, 21, 165-179.

Davis, MR, Grace, LJ, \& Horrell, RF. (1996). Conifer establishment in South Island high country: Influence of mycorrhizal inoculation, competition removal, fertiliser application, and animal exclusion during seedling establishment. New Zealand Journal of Forestry Science, 26(3), 380-394.

Dominati, E, Mackay, AD, Green, S, \& Patterson, M. (2011). The value of soil services for nutrient management. In Adding to the knowledge base for the nutrient manager. 24th Annual Fertiliser and Lime Research Centre Workshop (Vol. Occasional report No. 24, pp. 1-8). Palmerston North, New Zealand: Massey University.

Dymond, JR, Betts, HD, \& Schierlitz, CS. (2010). An erosion model for evaluating regional land-use scenarios. Environmental Modelling and Software, 25(3), 289-298.

Dymond, JR, Ausseil, A-GE, Ekanayake, JC, \& Kirschbaum, MUF. (2012). Tradeoffs between soil, water, and carbon - A national scale analysis from New Zealand. Journal of Environmental Management, 95(1), 124-131.

Ellis, JC, \& Hayes, JD. (1997). Field guide for sample plots in New Zealand forests. FRI Bulletin, No. 186. Rotorua, New Zealand: New Zealand Forest Research Institute.

Eyles, G, \& Fahey, B. (2006). The Pakuratahi Land Use Study. Hawkes Bay Regional Council.

Francescato, V, Scotton, M, Zarin, DJ, Innes, JC, \& Bryant, DM. (2001). Fifty years of natural revegetation on a landslide in Franconia Notch, New Hampshire, U.S. A. Canadian Journal of Botany, 79(12), 1477-1485.

Fransen, P, \& Brownlie, R. (1995). Historical slip erosion in catchments under pasture and radiata pine forest, Hawke's Bay hill country. New Zealand Forestry, 29-33.

Glade, T. (1998). Establishing the frequency and magnitude of landslide-triggering rainstorm events in New Zealand. Environmental Geology, 35(2-3), 160-174.

Haywick, DW, Lowe, DA, Beu, AG, Henderson, RA, \& Carter, RM. (1991). Pliocene-Pleistocene (Nukumaruan) lithostratigraphy of the Tangoio block, and origin of sedimentary cyclicity, central Hawke's Bay, New Zealand. New Zealand Journal of Geology \& Geophysics, 34(2), 213-225.

Hewitt, AE. (2010). New Zealand Soil Classification (3rd ed.). Lincoln, New Zealand: Manaaki Whenua Press.

Jones, J, Clough, P, Hock, BK, \& Phillips, C. (2008). Economic costs of hill country erosion and benefits of mitigation in New Zealand: Review and recommendation of approach. Wellington: Ministry of Agriculture and Forestry.

Kimberley, M, West, GG, Dean, MG, \& Knowles, RL. (2005). The 300 index - a volume productivity index for radiata pine. New Zealand Journal of Forestry, 50, 13-18.

Laganière, J, Angers, DA, \& Paré, D. (2010). Carbon accumulation in agricultural soils after afforestation. Global Change Biology, 16, 439-453.

Lambert, MG, Trustrum, NA, \& Costall, DA. (1984). Effect of soil slip erosion on seasonally dry Wairarapa hill pasture. New Zealand Journal of Agricultural Research, 27, 269-285.

Lambert, MG, Trustrum, NA, Costall, DA, \& Foote, AG. (1993). Revegetation of landslide scars in Wairarapa hill country. Proc NZ Grasslands Assn, $55,177-181$

Leco. (2003). Total/organic carbon and nitrogen in soils (LECO Corporation). St Joseph, MO: Organic application note 203-821-165.

Lee, JM, Bland, KJ, Townsend, DB, \& Kamp, PJJ. (2011). Geology of the Hawke's Bay area, Institute of Geological and Nuclear Sciences 1:250,000 geological map 8.1 sheet +93 p. Lower Hutt: GNS Science.

Lowe, DJ, Blaauw, M, Hogg, AG, \& Newnham, RM. (2013). Ages of 24 widespread tephras erupted since 30,000 years ago in New Zealand, with re-evaluation of the timing and palaeoclimatic implications of the late-glacial cool episode recorded at Kaipo bog. Quaternary Science Reviews, 74, 170-194.
Lynn, IH, Manderson, AK, Page, MJ, Harmsworth, GR, Eyles, GO, Douglas, GB, Mackay, AD, \& Newsome, PJF. (2009). Land Use Capability Survey Handbook

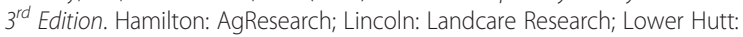
GNS Science.

MAF. (2011a). http://www.maf.govt.nz/news-resources/statistics-forecasting/forestry/ indicative-new-zealand-radiata-pine-log-prices.aspx. Accessed 1 June 2011.

MAF. (2011b). http://www.maf.govt.nz/news-resources/statistics-forecasting/ forestry/log-grade-specification.aspx. Accessed January 112011.

Mead, DJ, \& Gadgil, R. (1978). Fertiliser use in established radiata pine stands in New Zealand. New Zealand Journal of Forestry Science, 8, 105-134.

Newsome, PFJ, Wilde, RH, \& Willoughby, EJ. (2008). Land resource information system spatial data layers. Land Resource information system spatial data layers (pp. 72). Palmerston North: Landcare Research.

NIWA. (2010). Cliflo: The National Climate Database. http://cliflo.niwa.co.nz/. Accessed 18 June, 2012.

Page, MJ, Trustrum, NA, \& Dymond, JR. (1994). Sediment budget to assess the geomorphic effect of a cyclonic storm, New Zealand. Geomorphology, 9(3), 169-188.

Page, MJ, Reid, LM, \& Lynn, IH. (1999). Sediment production from Cyclone Bola landslides, Waipaoa catchment. Journal of Hydrology New Zealand, 38(2), 289-308.

Palmer, DJ, Watt, MS, Kimberley, MO, Hock, BK, Payn, TW, \& Lowe, DJ. (2010). Mapping and explaining the productivity of Pinus radiata in New Zealand. New Zealand Journal of Forestry, 55(1), 15-21.

Parfitt, RL, \& Ross, DJ. (2011). Long-term effects of afforestation with Pinus radiata on soil carbon, nitrogen, and pH: a case study. Soil Research, 49, 494-503.

Paul, Kl, Polglase, PJ, Nyakuengama, JG, \& Khanna, PK. (2002). Change in soil carbon following afforestation review Forest. Ecology and Management, $168,241-257$

Pawson, SM, Brockerhoff, EG, Meenken, ED, \& Didham, RK. (2008). Non-native plantation forests as alternative habitat for native forest beetles in a heavily modified landscape. Biodiversity and Conservation, 17(5), 1127-1148.

Phillips, C, Marden, M, \& Rowan, D. (1989). Planning for forestry after Cyclone Bola, a comment. November: New Zealand Forestry.

Pine Manufacturers. (2013). New Zealand pine users guide: log quality and conversion. http://www.pine.net.nz/component/content/article/5-technicalspecs/85-nz-pine-user-guide. Accessed 2 March 2013.

Restrepo, C, Vitousek, P, \& Neville, P. (2003). Landslides significantly alter land cover and the distribution of biomass: An example from the Ninole ridges of Hawai'i. Plant Ecology, 166(1), 131-143.

Rosser, BJ, \& Ross, CW. (2011). Recovery of pasture production and soil properties on soil slip scars in erodible siltstone hill country, Wairarapa, New Zealand. New Zealand Journal of Agricultural Research, 54(1), 23-44.

Salinger, MJ, \& Mullan, AB. (1999). New Zealand climate: temperature and precipitation variations and their links with atmospheric circulation 1930-1994. International Journal of Climatology, 19, 1049-1071.

Serengil, Y, Swank, WT, Riedel, MS, \& Vose, JM. (2011). Conversion to pine: Changes in timing and magnitude of high and low flows. Scandinavian Journal of Forest Research, 26(6), 568-575.

Skinner, MF, Lowe, AT, Nicholson, GM, \& Prince, J. (1991). Availability of phosphorus in New Zealand forest soils: a new approach with the Bray reagent. In RE White \& LD Currie (Eds.), Soil and Plant Testing for Nutrient Deficiencies and Toxicities (pp. 143-147). Massey University: Palmerston North: Massey University Occasional Report No. 5.

Smith, RB, Commandeur, PR, \& Ryan, MW. (1986). Soils, vegetation, and forest growth on landslides and surrounding logged and old-growth areas on the Queen Charlotte Islands. Victoria, B.C: Land Management Report No. 41. Canadian Forestry Service.

Thompson, CS. (1987). The climate and weather of Hawke's Bay (Vol. 5, 115). Wellington: New Zealand Meteorological Service.

Trustrum, NA, Lambert, MG, \& Thomas, VJ. (1983). The impact of soil erosion on hill country pasture production in New Zealand. Paper presented at the Second International Conference on Soil Erosion and Conservation. Hawaii: Honolulu.

West, GG, Moore, JR, Shula, RG, Harrington, JJ, Snook, J, Gordon, JA, \& Riordan, MP. (2012). Forest management DSS development in New Zealand (Paper presented at the 1st International Scientific Conference, Implementation of DSS into the forestry practice, pp. 10-12). Zvolen, Slovakia: Technical University.

\section{doi:10.1186/s40490-014-0024-5}

Cite this article as: Heaphy et al:: Assessing drivers of plantation forest productivity on eroded and non-eroded soils in hilly land, eastern North Island, New Zealand. New Zealand Journal of Forestry Science 2014 44:24. 